\title{
Deconstructing the notion of blame in corporate failure ${ }^{\text {is }}$
}

\author{
John Pal ${ }^{\mathrm{a}, *}$, Dominic Medway ${ }^{\mathrm{b}}$, John Byrom $^{\mathrm{c}}$ \\ a Marketing and Retail Division, Manchester Metropolitan University Business School, Aytoun Street, Manchester, M1 3GH, United Kingdom \\ ${ }^{\mathrm{b}}$ Marketing Subject Group, Manchester Business School, University of Manchester, Booth Street West, Manchester, M15 6PB, United Kingdom \\ c School of Management, University of Tasmania, Locked Bag 1316, Launceston, Tasmania 7250, Australia
}

\section{A R T I C L E I N F O}

\section{Article history:}

Received 1 December 2009

Received in revised form 1 June 2010

Accepted 1 November 2010

Available online 28 November 2010

\section{Keywords:}

Corporate failure

Retailing

Blame

Culpability

\begin{abstract}
A B S T R A C T
Corporate failure is the subject of considerable academic debate since the $1960 \mathrm{~s}$. Failure in the retail sector receives less attention however. This paper addresses the notion of blame in corporate failure. Reference to $\mathrm{A}$ Goldberg and Sons, a failed retailer, exemplifies the discussion. Prior to bankruptcy in 1990, this firm was a successful Scottish department store and clothing retailer. The study takes a historical approach, using indepth interviews, archival material, and other secondary data sources. Findings reveal that, despite warning signs from various key performance indicators and external reviews, the company's board failed to act appropriately. A series of bad strategic decisions contributed to the company's failure. In line with theories of blame attribution, through their (in)actions, the board's negligence played a major role in the firm's demise.
\end{abstract} (c) 2010 Elsevier Inc. All rights reserved.

\section{Introduction}

The role of failure within organizations is a subject of investigation across various business and management disciplines (Mellahi and Wilkinson, 2004). Substantial academic and practitioner attention focuses on understanding the reasons why companies decline and eventually cease to operate. In addition, recent macroeconomic conditions precipitated by the global financial crisis have led to the folding of several high-profile firms in the financial sector. Failure is clearly a pertinent phenomenon. Whilst numerous studies, both academic (Arnold, 2002; Berry et al., 1997; Bird and Witherwick, 1986; Gardner, 1995; Howe, 2000; La Vere and Kleiner, 1997; Maltz et al., 2003; Michman and Greco, 1995; Miller and Merrilees, 2000; Sparks, 2003) and non-academic (Andersen, 1997; Chapman, 1974; Davies, 1991; Jones, 2005; MacLaurin, 1999; Powell, 1991; Richer, 1998; Sieff, 1986, 1991; Walker, 1978) cite the successful development of retail firms, less attention is paid to retail failure. Indeed, only in the last decade or so does the literature address the subject (Gold and Woodliffe, 2000; Lightfoot, 2003; McGurr and Devaney, 1998a; Turner, 2003), with particular focus on apparently failing companies such as Marks \& Spencer (M\&S) (Burt et al., 2002; Mellahi et al., 2002).

This paucity of literature on retail failure is surprising considering the amount on corporate failure more generally. This paper explores the issue of blame in relation to corporate failure, and deconstructs

\footnotetext{
The authors acknowledge the helpful insights and suggestions received from Cathy Bakewell, Gary Davies and Gary Warnaby.

* Corresponding author. Tel.: +44 161247 3988; fax: +44 1612476305.

E-mail addresses: johnwpal@yahoo.co.uk (J. Pal), dominic.medway@mbs.ac.uk (D. Medway), john.byrom@utas.edu.au (J. Byrom).
}

blame in the context of one retailer's collapse. Until the firm's demise, the story of Scottish retailer A Goldberg and Sons (AGS) is a classic rags to riches tale: one of Jewish immigrant endeavor, typical of other great retail institutions such as M\&S (Bevan, 2001), Tesco (Seth and Randall, 1999), and Macy's (Harris, 1979). In the early 1900s, AGS was established. The company expanded steadily throughout the 20th century. At the firm's zenith in 1989, AGS traded from 120 stores and six fascias, with a turnover of almost $£ 60$ million (US\$101.1 million at 1989 rates) and a gross profit of $£ 4$ million. By June 1990, however, AGS had ceased trading.

The investigation draws on notions of blame found in the social psychology literature, and specifically Shaver's (1985) sequential model of blame attribution (see Fig. 1). Shaver argues that the attribution sequence of blame starts on the left-hand side of his model with all the actions a potentially blameworthy person/organization might have performed. Actions with negative consequences can be examined by proceeding from left to right through the model and considering the attribution of causality, the dimensions of responsibility and the determination of blameworthiness. At various stages, certain actions that will not meet successive tests for potential blame 'sheer off' to provide a variety of blame attribution outcomes. Shaver (1985: 165-173) provides further details on this process. On the basis of Shaver's model the following research questions follow in relation to A. Goldberg and Sons. (1) Did the company's directorate have knowledge of impending failure? (2) To what extent was the board's decision-making the cause of that failure? (3) Who, if anybody, is culpable for that failure?

Research question one draws on notions of foreseeability in blame attribution from Shaver's model. Question two draws on the role of causality in Shaver's blame attribution process. Question three concerns 


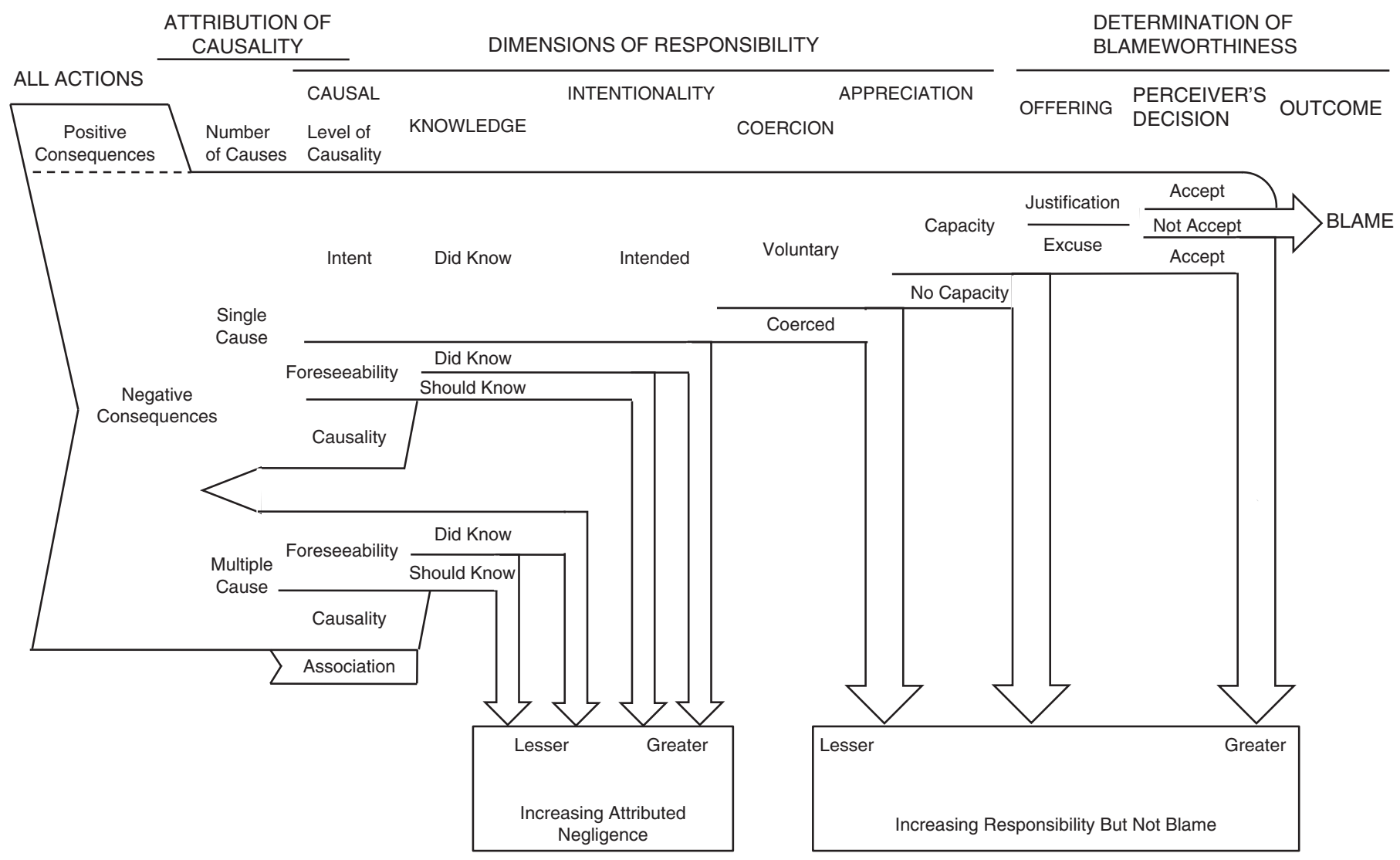

Fig. 1. Shaver's (1985) sequential model of blame attribution.

the concept of the dimensions of responsibility and, in certain instances, blameworthiness. The concept of blame is under-researched in business and management, yet deserves closer attention. Specifically, focus on the above research questions, as well as providing insights into blame attribution at AGS, may also enrich understanding of other corporate failures.

\section{Corporate failure}

A number of key foci characterize the issue of corporate failure in academic literature. One relates to defining the term failure in a business context. The use of synonyms such as collapse, decline, breakdown and demise confuses this task. Researchers in the finance area suggest failure equates to bankruptcy or insolvency (Altman, 1968; Altman et al., 1977; Beaver, 1966; Bhargava et al., 1998; McGurr and DeVaney, 1998b; Sharma and Mahajan, 1980). By contrast, Morris (1997, p. 2) defines failure as embracing "various types of financial distress, ranging from bankruptcy at one extreme to decline in profitability at the other". The few studies of retail "failure" imply it can be a temporary phenomenon (Mellahi et al., 2002; Burt, Dawson, and Sparks, 2003).

The literature on corporate failure adopts distinct approaches, and work in the corporate finance discipline centered on econometric analysis and failure prediction is one key research stance in this respect (Beaver, 1966; Altman, 1968; Altman et al., 1977; Altman and Narayanan, 1997; Balcaen and Ooghe, 2006; McGurr and DeVaney, 1998a,b; Morris, 1997; Rauh, 1989/1990; Taffler, 1984). A second research approach emanates from organizational studies. Mellahi and Wilkinson (2004) conceptualize the main aspects of this work as a duality between those stating that company failure is due to largely uncontrollable macro-environmental factors, and those who contend such failure is due to what goes on internally in terms of controllable management decision-making.

\subsection{Blame in corporate failure}

The concept of blame is complex in any analysis of corporate fortunes. First, blame is chronologically restricted and is applicable only to past events and actions. A second characteristic is that anyone can cast blame. Indeed, when blame is laid at the door of businesses in incidences of bankruptcy (e.g. Enron and Rover), perceived mismanagement (e.g. Northern Rock, The Royal Bank of Scotland), or suspected corporate negligence resulting in injury or death (e.g. the Bhopal gas disaster, or the BP Texas oil explosion), then that blame can come from the media, members of the public, or government.

The issue of blame receives significant consideration in the social psychology literature (e.g. Hamilton, 1978; Hamilton et al., 1998; Shaver, 1985), where two key themes arise. The first concerns the link between employees' hierarchical positions in an organization and how these link to credit and blame. Gibson and Schroeder (2003), for example, found that leadership roles in organizations attract more blame than credit, whilst lower-level positions tend to attract more credit than blame. A second theme is that senior management "tend to credit themselves for positive outcomes and blame negative results on the [external] environment" (Tsang, 2002: 51). Others have argued that such behavior is a marker of complacent management (Wagner and Gooding, 1997).

Another key issue is that human nature links culpability to people and, more specifically, to individuals, rather than to faceless and inanimate organizations (Gibson and Schroeder, 2003). Inevitably, therefore, when companies fall into crisis, senior figures such as CEOs end up shouldering the brunt of criticism (Sull, 2005a). Yet Sull (2005b) suggests that these individualized targets for blame are often unfounded, and perhaps even unfair. He contends that active inertia (typically a collective board level responsibility, and thereby a group activity too) is what typically leads to corporate failure. 
Table 1

Timeline of Goldberg's development under Mark Goldberg's chairmanship.

\begin{tabular}{|c|c|c|c|c|c|c|c|}
\hline & \multirow[t]{2}{*}{ Year } & \multirow[t]{2}{*}{ Key event/activities of the firm } & \multicolumn{5}{|l|}{ Store openings } \\
\hline & & & $\begin{array}{l}\text { Goldberg 'town } \\
\text { stores' }\end{array}$ & Wrygges & Wrygges Man & Schuh & Ted Baker \\
\hline \multirow[t]{4}{*}{$\begin{array}{l}\text { Phase One: Consolidates and } \\
\text { innovates out of trouble }\end{array}$} & 1975 & $\begin{array}{l}\text { Records declining, turnover and productivity (see Figs. } 2 \text { and } 3 \text { ), and a } \\
\text { reduction in earnings for first time in } 30 \text { years. Installs Europe's first } \\
\text { on-line EPOS system }\end{array}$ & & & & & \\
\hline & 1976 & $\begin{array}{l}\text { Withdraws from attempts to diversify into contract furnishing and } \\
\text { superstore retailing. Closes distribution centre and two unprofitable stores }\end{array}$ & & & & & \\
\hline & 1977 & Launches Wrygges on trial basis in Glasgow store. & 1 & & & & \\
\hline & 1978 & Installs EPOS in all stores. & 4 & & & & \\
\hline \multirow[t]{6}{*}{$\begin{array}{l}\text { Phase Two: Develops products } \\
\text { and credit card operation }\end{array}$} & 1979 & $\begin{array}{l}\text { Raises } £ 2.4 \mathrm{~m} \text { in } 1 \text { for } 3 \text { rights issue to develop Wrygges concept which } \\
\text { opens on concession basis in Goldberg 'town stores'. }\end{array}$ & 1 & 15 & & & \\
\hline & 1980 & Opens first store in England (Blackpool). & 1 & & & & \\
\hline & 1981 & $\begin{array}{l}\text { Announces launch of Style Card against backdrop of rising } \\
\text { unemployment. Directors participate in Harvard MOE program. }\end{array}$ & & & & & \\
\hline & 1982 & Opens new distribution centre. & 2 & & & & \\
\hline & 1983 & $\begin{array}{l}\text { Announces that Blackpool store makes its first profits. Directors } \\
\text { participate in second Harvard MOE program. }\end{array}$ & & & & & \\
\hline & 1984 & $\begin{array}{l}\text { Opens three standalone Wrygges stores in northern England. Funding } \\
\text { debt on Style Card operation becoming costly. }\end{array}$ & & 5 & & & \\
\hline \multirow{6}{*}{$\begin{array}{l}\text { Phase Three: Invests Style } \\
\text { proceeds in rapid expansion } \\
\text { into new products and } \\
\text { markets }\end{array}$} & 1985 & $\begin{array}{l}\text { Sells } 60 \% \text { of Style Card to Royal Bank of Scotland (RBS). For } £ 4.8 \mathrm{~m} \text { but } \\
\text { records drop-in pre-tax profits (see Fig. } 2 \text { ) }\end{array}$ & & & & & \\
\hline & 1986 & $\begin{array}{l}\text { Acquires and converts 21-store chain Virgo into Wrygges/Wrygges } \\
\text { man; refits stores. }\end{array}$ & & 13 & 5 & & \\
\hline & 1987 & $\begin{array}{l}\text { Continues store refits. Plans to have } 100 \text { Wrygges stores within three } \\
\text { years. Acquires Schuh. Enters joint venture with Personal Contact } \\
\text { Group (PCG) to develop Ted Baker. Charterhall begins stake building } \\
\text { in AGS shares }\end{array}$ & & 5 & & 22 & \\
\hline & 1988 & $\begin{array}{l}\text { Sells remaining } 40 \% \text { of Style to RBS for } £ 5.9 \mathrm{~m} \text {. Acquires PCG and } \\
\text { continues store openings in England despite difficult trading } \\
\text { environment. }\end{array}$ & & 14 & & 11 & 7 \\
\hline & 1989 & $\begin{array}{l}\text { Rejects all-paper bid for Blacks that has backing of Charterhall's } 29.9 \% \\
\text { holding. Reports first-ever losses caused by economic downturn and } \\
\text { over-capacity of retail space. }\end{array}$ & & & & 1 & 1 \\
\hline & 1990 & Ceases trading. & & & & & \\
\hline
\end{tabular}

Very little discussion of blame exists in the small number of studies discussing retail failure, although some researchers allude to the notion (Mellahi et al., 2002; Burt et al., 2003). In both these cases, any hint of blame attribution lies with senior executives of the retailers in question, a point that resonates with Sull's observations (2005b). Discussion of blame in this paper focuses on those with a boardroom role at AGS. This focus is understandable bearing in mind the strategic decision-making role that directors play in a company's trajectory. The approach is also in line with literature on blame and credit attribution in organizations, where those in leadership roles are more likely to be the target of blame, and where directors may attempt to deflect blame for negative outcomes on to external environmental factors.

\section{An overview of AGS}

Abraham Goldberg started his business selling cloth in Glasgow in the early 1900s before moving into department store retailing. His unique selling proposition was extending lines of credit through customer accounts. Grandson Mark Goldberg joined the firm in 1963 and became chairman in 1974. From 1969 to 1974 the company opened scaled-down versions of their main department stores (referred to as 'town stores') across Scotland. Customers could gain access to three months' interestfree credit of up to 24 times their monthly payment and by the early 1970s, 350,000 customers held accounts.

During Mark Goldberg's chairmanship AGS went through three distinct phases (see Table 1). Phase one (1975-1978) was the refocusing of the Scottish-based store network with a store rationalization program and the development of a new womenswear product, Wrygges. Alongside this, the company became the first European retailer to install EPoS (Electronic Point of Sale).

The second phase (1979-1984) involved the rollout of the Wrygges format and the beginning of the company's locational expansion into
England. Customer credit accounts were transferred on to the newly launched Style Card in this phase, which by 1983 could be used in a number of non-competing retailers. This period also saw two directors participate in Harvard Business School's Managing Organizational Effectiveness Program.

Phase three (1985-1990) saw the company facing problems of financing the growing debt associated with the Style Card operation. Accordingly, AGS sold the Style Card to the Royal Bank of Scotland. Proceeds from the sale were invested in a variety of retail initiatives, most notably the acquisition of the 21-store Virgo fashion chain, based in central Scotland. These were rebranded as the standalone Wrygges and nascent Wrygges Man fascias. In addition, AGS acquired the three-store Schuh chain, a footwear retailer, and entered into a joint venture with Personal Contact Group to develop Ted Baker, then a men's shirt retailer. Towards the end of this phase, the Wrygges format became available across England.

From 1987 to 1989, an Australian investment company, Charterhall, built up a $29.9 \%$ stake in AGS. An all-paper bid by Black's Leisure for AGS, with the backing of the Charterhall stockholding, failed in 1989. Early 1990 saw the appointment of an externally-recruited CEO. A number of Wrygges stores in England closed in early 1990 and many of the remaining outlets rebranded as News. The final hours of the firm saw AGS seeking a reverse takeover with investment company Fletsland (Bowditch, 1990). AGS went into receivership in June 1990 and ceased trading in September. Schuh and Ted Baker continue to trade to this day under different ownership.

\section{Method}

This study draws on a variety of data sources including the AGS archive (UGD 354 A Goldberg and Sons plc archive, n.d) at Glasgow University. Archive material from the beginning of Mark Goldberg's 
chairmanship in 1974 to the eventual insolvency in 1990 was drawn on, thereby constituting the study period. Data from the archive were collected through a process of note-taking, permitted photocopying and photography. The study also draws on share price data from 1974 for AGS and two other benchmark retailers, enabling examination of the company's relative performance. These data are triangulated with critical commentary on AGS's share performance from the press and equity brokers' notes.

Additional data gathering included in-depth exchanges with five former AGS directors: four through in-depth interviews and one via email. These interviewees are referred to as Directors A to E to preserve anonymity. The interviews were analyzed using techniques of theme and content analysis. Heightened interpretation of the interview themes was gained by engaging in dialogue with six current experts in retail analysis. During the interviews, a director revealed that a court case occurred after the demise of AGS, relating to the nonpayment to RBS of monies lodged with AGS by Style Card customers. The court proceedings are an additional data source.

The historical method to research in marketing is a method that Golder (2000, p. 157) suggests as useful "in many more [studies], specifically those with longitudinal or archival data" (see also, Thompson, 2010). This paper employs such data and thereby rises to Golder's challenge. The wide variety of data collection and interrogation approaches taken, and their subsequent integration and triangulation, also helps deepen understanding of AGS's eventual failure. This paper provides only one interpretation of a complex series of events, however.

\section{Findings}

\subsection{Foreseeability}

The first question concerns whether or not the AGS directorate had any knowledge of the impending failure of the company; and if not, could and should they have had based on information that was available to them? Various key performance indicators (KPIs) provide differing pictures of the company's trajectory. For example, between 1974 and 1989 AGS demonstrates steady increases in retail sales turnover $(1974=£ 13.8$ million, $1989=£ 59.1$ million $)$ and sales per square foot $(1974=£ 90$ per sq ft, $1989=£ 150$ per sq ft). However, pre-tax profit shows a more mixed picture of fluctuating performance (Fig. 2). Further investigation also shows an overall decline in sales per square foot and pre-tax profit per square foot for the period
(Fig. 3) when the data are indexed and re-based to take account of inflation, suggesting that inflation masks underlying problems.

Beyond the differing raw data, a number of prediction models exist that purport to foresee the failure of firms. One of the longest standing and most easily applicable models is that of Deakin (1972), which uses return on assets (RoA) as a key metric. Fig. 4 presents the Deakin failure prediction model for AGS from 1974 to 1989, benchmarking the company against two other key British retailers for that period: Burton and M\&S.

Deakin's model predicts failure for AGS twice. The first time this occurs is between 1982 and mid-1985, by which time the sale of the Style Card seemingly lifts the company's fortunes and averts a crisis. This sale was arguably the opportunity for a business turnaround, an issue explored later. By early 1988, the model is again predicting failure, and by June 1990 proves correct. However, the model also predicts that Burton should have failed anytime in the late 1970s, yet the company did not. Overall, these results suggest that failure prediction models indicate potentially troublesome trends, but given that companies can survive and recover from periods in the supposed failure zone, their predictive use is perhaps limited. Notwithstanding, AGS management were aware of such performance trends; as Director A put it: "we were aware instantly when things were sliding". Any awareness of such data (irrespective of the efficacy of the failure prediction models using it) raises further questions about foreseeability of failure and blame attribution amongst AGS's directorate.

Using share price data is another way of identifying potentially failing companies. As Morris (1997, p. 271) explains: "share prices tend to anticipate messages conveyed by failure prediction models". Fig. 5 shows AGS's share price fluctuations, together with key phrases and events from various studies, analysts' reports (Bubb, 1983; Bubb, 1984; Dorgan, 1984) and press comments, throughout the 1980s. The fluctuations in the share price point to patchy investor confidence in the company's future. Nevertheless, the healthy trajectory of share price following the sale of the Style Card in mid-1985 through to mid1988 may have allayed fears about problems and potential failure in the company, amongst not only company directors, but also City analysts. In addition, a comparison of AGS's share price during the 1980s with those of Burton and M\&S reveals similar fluctuations, suggesting investor sentiment was broadly in line across the retail sector (Fig. 6). However, two notable differences are apparent. The first occurs after the sale of the Style Card when AGS shares outperform the benchmark retailers, recording a rise in excess of 200\% from April 1985 to May 1986. The second arises prior to AGS's denouement, in the period from August 1989 to May 1990, when the company underperforms relative to the other two retailers.

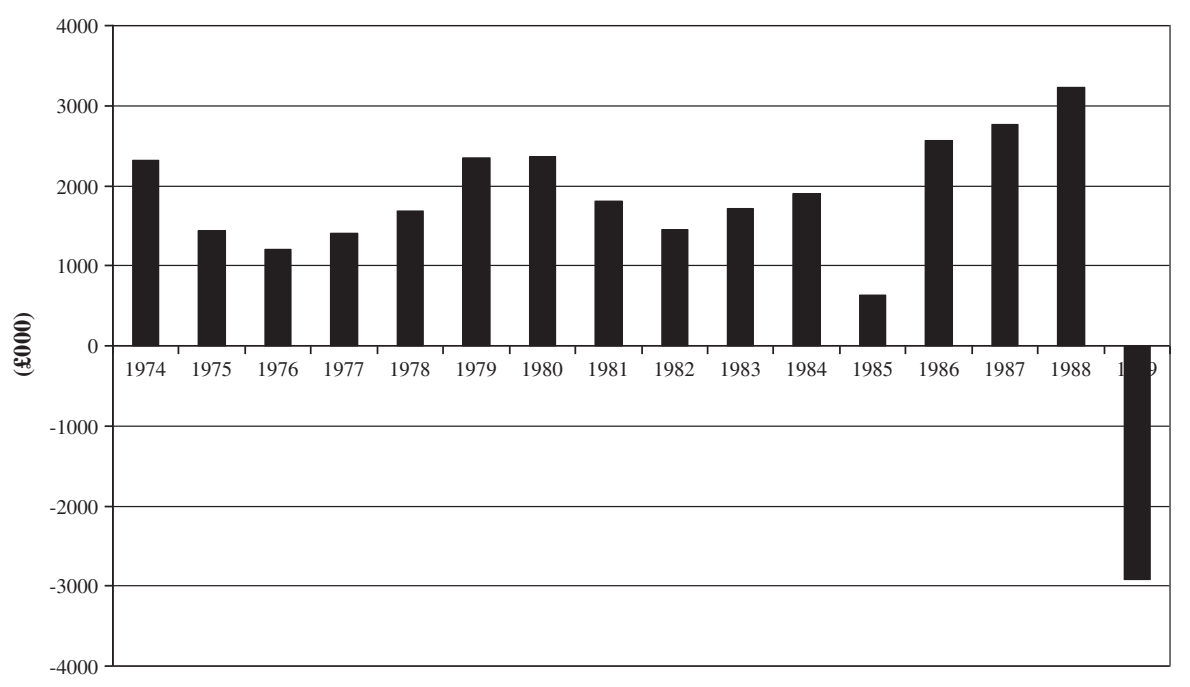

Fig. 2. AGS's pre-tax profit, 1974-1989. 


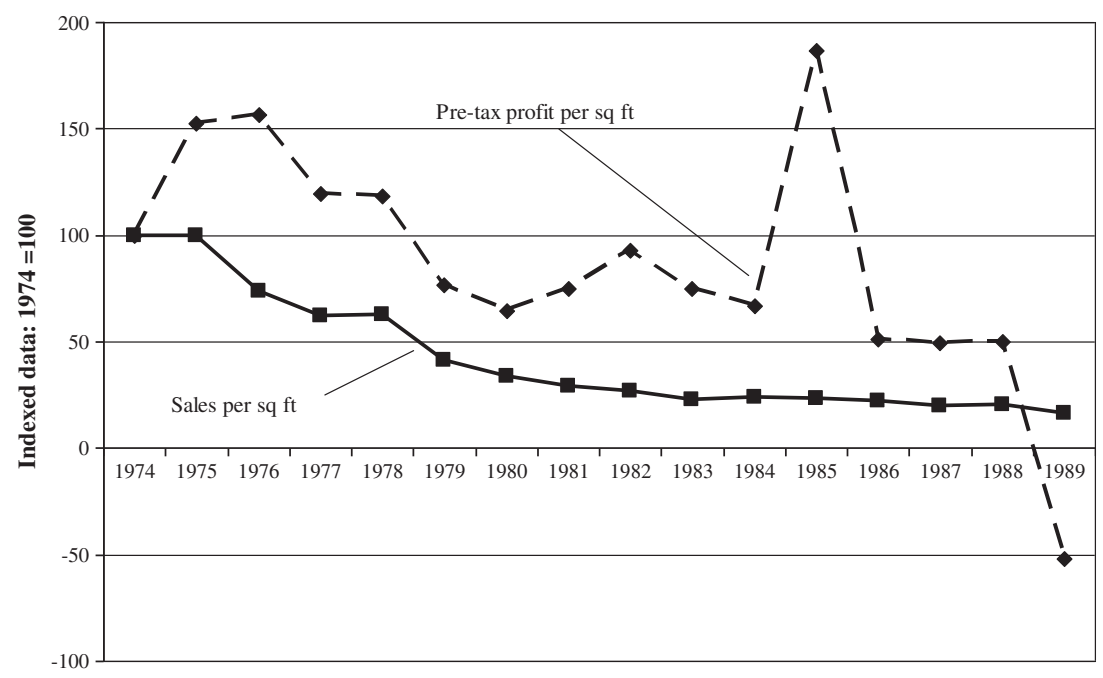

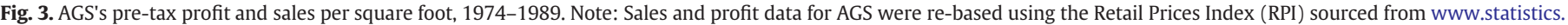
gov.uk/downloads/theme_economy/RP02.pdf. These re-based data were then indexed to 100 using the methodology adopted by O'Donoghue et al. (2006, p. 39).

On first take, these various forms of financial data suggest a mixed picture. Thus, whilst the share price demonstrates periods of rally, and there are healthy rises in retail sales and pre-tax profit per square foot, other calculations, which take into account inflation or the RoA data used in failure prediction models, show a more downbeat picture. However, the directorate was aware of the warning signals. Indeed, one former director comments that detailed interrogation of the financial data was something AGS was quite good at from an early stage:

From the early '60s to the later years when we did become more sophisticated, we were planning. Because we had the technology, it was very easy to produce results quickly and compare actuals with the plan. (Director B)

The company's annual reports of the 1980s are upbeat about matters such as expansion, and the positive story this delivered in terms of

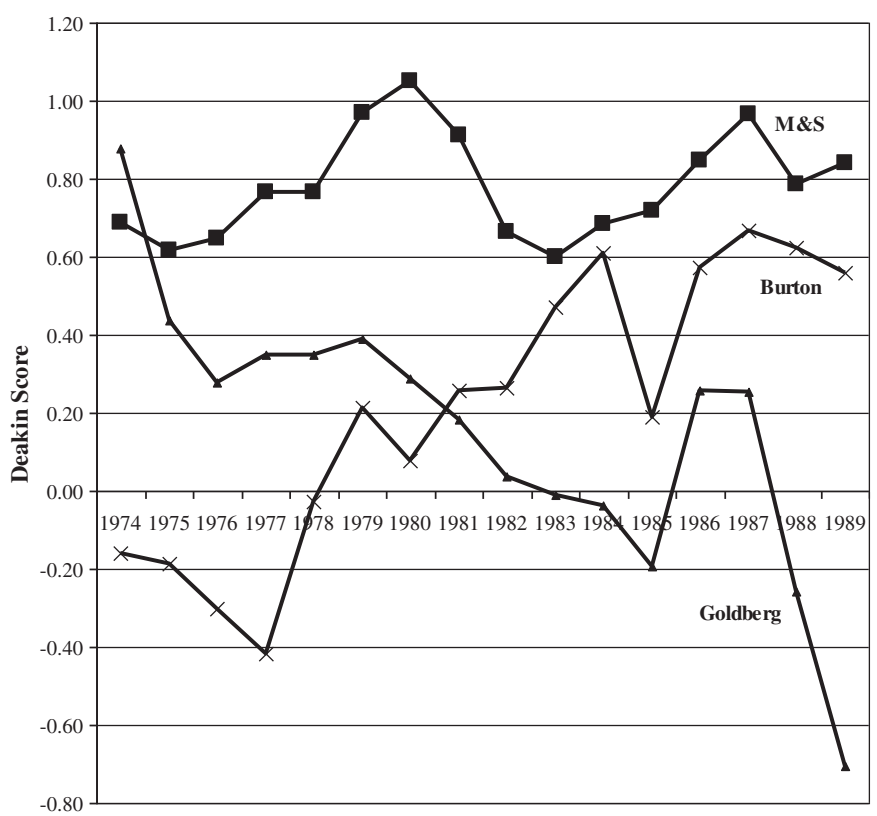

Fig. 4. Deakin's Failure Prediction Model. $-0.2587+(5.966 *$ Return on assets). Negative score predicts failure. growing floor space and turnover, but are also candid about not meeting sales expectations. For example, the 1983 report talks of being:

... encouraged by significant progress in our recently opened regional stores... [and] confident that further drive on efficiency and productivity, together with controlled and aggressive investment in the future, will enable the company to maintain steady growth in the coming years. (A Goldberg and Sons, 1983)

Yet, the same report also notes that:

The pattern of trading... has been very much as expected... [and] there appears to be no evidence for economic improvement in our trading markets.

As with many annual reports, the more disappointing data are justified in terms of trends in the wider market, such as the national economy and the weather, as well as temporary structural upheaval in the company. Hence, the 1983 annual report also states that, "Retailing activities continue to be adversely affected by current economic conditions and further increases in occupancy costs" (A Goldberg and Sons, 1983). What the above emphasizes is the difficulty in determining how much directors are genuinely affected by (and believe in) disappointing figures and indicators, against the degree to which they accept their own (sometimes unrealistic) positive spin about these. In the case of AGS, any positive spin of the financials was clearly not realistic in hindsight. Using other data sources allows further examination of the issue.

First, cross-referencing other archival information with the company reports is revealing. The 1986 annual report, for example, notes that the:

... level of profit underlines... the merits of the action we have taken to revitalize our business... We have also refitted our Goldberg stores in East Kilbride and Clydebank and initial results are equally encouraging. (A Goldberg and Sons, 1986a)

Yet a board level report states, "Goldberg stores-the poor performance of the refitted stores is being investigated" (A Goldberg and Sons, 1986b). Excerpts from the interviews also illustrate how the directors perceived financial data as the following quotation exemplifies:

I think we were haunted by performance all the time. We were always beating ourselves up about performance... It was always touch and go. (Director A) 


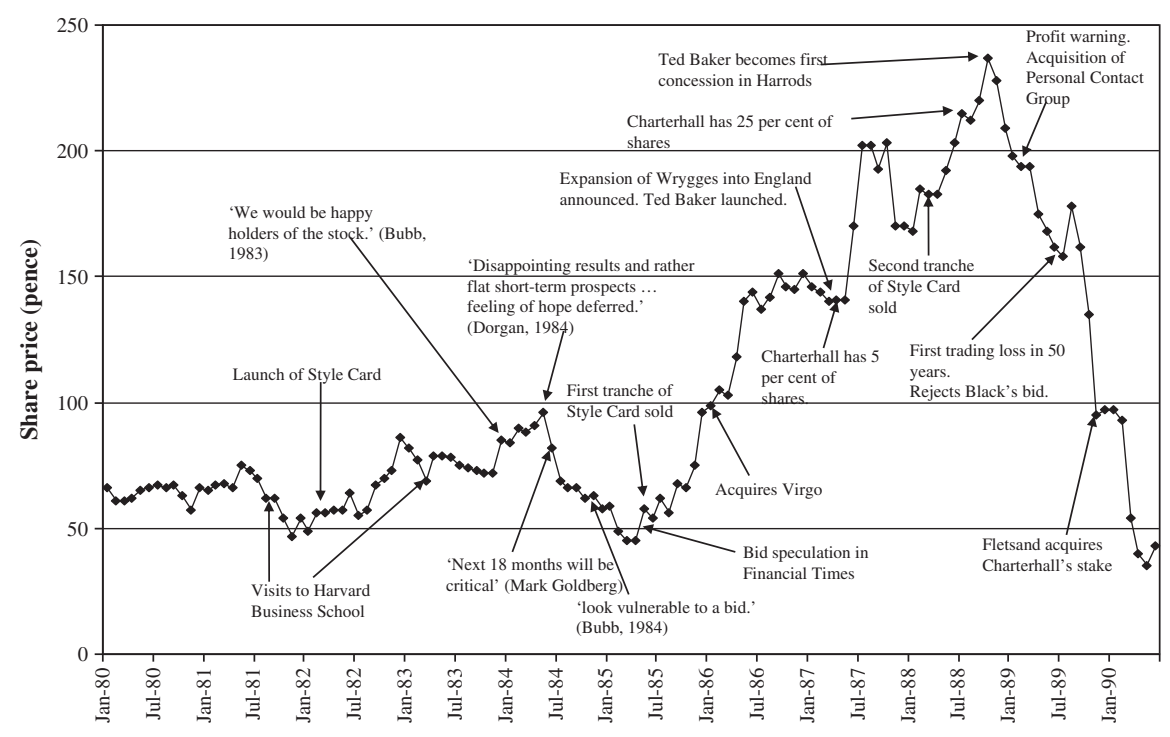

Fig. 5. AGS share price annotated with key events and phrases in the firm's last decade. Source: Various, including documents held within UGD354.

Clearly, beneath some of the positive messages of the AGS annual reports the directors had common knowledge that the company was in a poor financial state, suggesting they did envisage the potential for failure.

Finally, regarding the question of whether the directors had knowledge of impending failure, attention turns to a 1997 court case relating to AGS's bankruptcy (Scottish Civil Law Reports, 1997). This provides additional evidence to suggest that the company's bankers (the Bank of Scotland) and AGS directors were fully aware of the company's parlous state long before the eventual bankruptcy. In August 1989, the bank was requiring AGS to provide security for what had been a constant overdraft for at least five months. By September, AGS provided this security in the form of their two large freehold stores in Glasgow and Edinburgh. Subsequently, Style Financial Services, now owned by RBS, also sought security on the money AGS held over on their behalf each month, and which was actually helping to deflate the worst excesses of their overdraft.
In response, Mark Goldberg said, "there was nothing Goldberg could do" (Scottish Civil Law Reports, 1997, p. 15), because they had already given all their security in respect of the Glasgow and Edinburgh stores to their own bank. In short, they had no fixed assets remaining against which to secure anything. This sequence of events began up to 14 months before the calling in of the receivers. In answer to the first research question, therefore, the directorate was aware of the potential for failure sometime before the company folded.

\subsection{Causality}

Revisiting the major decisions taken at AGS allows the paper to fulfill the second objective. Some of the early decisions indicate a company at the cutting edge of the retail industry, capable of taking first-mover advantage. The introduction of EPoS and the development of the Style Card, an early version of the store cards latterly introduced by many retailers, are examples of the level of innovation.

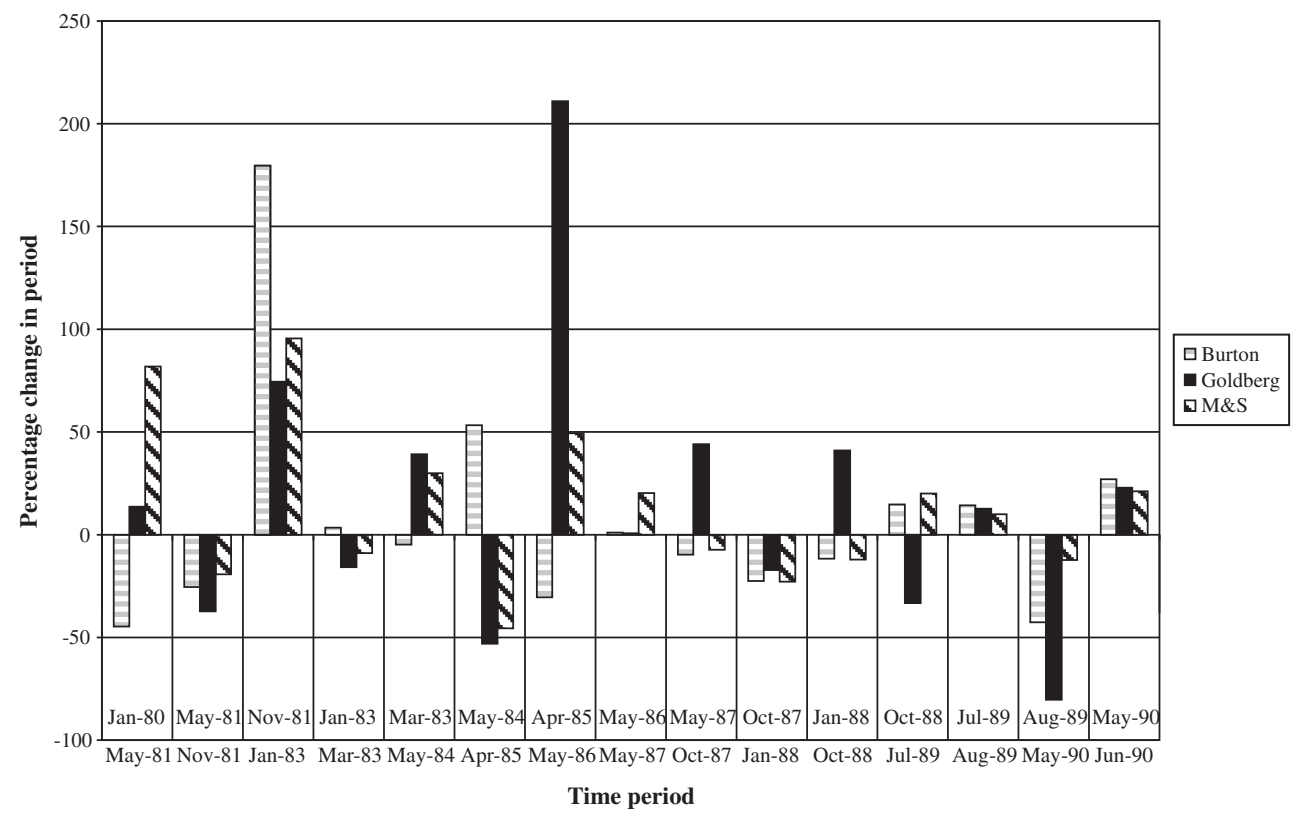

Fig. 6. Share price movements for AGS and two comparative retailers. 
The first of a series of linked decisions made by the board, which arguably fed through to company failure, occurred in 1983 when AGS allowed other non-competing retailers to accept the Style Card. Although split over the idea, the board saw the card's rollout as a means of widening customer appeal. Yet the level of debt that began to be incurred in servicing this extended credit led to the board (under pressure from its bankers) sanctioning the card's sale in 1985. Although one interviewee noted that AGS might have been better off retaining the Style Card, as it had become the company's unique proposition as a retailer:

With hindsight... I was quite upset because I'd been very close to the business and I really believed they were doing a weak sell. They were selling the crown jewels as far as I was concerned because that (i.e. the Style Card) is what Goldberg's were. (Director D)

The sale of Style represented a cash windfall for AGS and left the company debt free. The natural home for the proceeds was in a reinvestment in the core retail business, even though arguably the core business prior to the sale had been the Style Card itself. It seems the Style money panicked the board from within:

There was pressure that we willy-nilly imposed on ourselves by selling Style and announcing ourselves as retailers. (Director B)

Similar boardroom tensions were externally generated. Director B noted that bankers, analysts, and financial experts, were all bringing pressure to bear on the company by saying:

Well if you're retailers and you've expanded throughout Scotland, and there's nowhere else you can go in Scotland, then it's England.

Whatever the source of the impetus for change, following the sale of Style AGS's role as a retail company became clear-a position subsequently emphasized through aggressive territorial expansion of the store network. Despite this plan, little retail or location expertise was apparent at board level:

When we started to move out of town we didn't have any what I would call retailers at the table, we had historically credit management, credit administration, accounting, a facilities management man, a marketing man, but no real buy or sell guy. (Director D)

In using proceeds from the sale of Style for retail expansion lay further linked and problematic decisions, not least in terms of timing. As one former director noted:

It was unfortunate for Mark Goldberg. The board got their hands on this money to expand the retail operation just at the time property values were at their highest. Interest rates and everything were just monstrous. (Director D)

Clearly, the decision to expand the store network into England was not only rushed, but also poorly judged in terms of events occurring in the UK economy, suggesting the company was paying scant regard to the most basic environmental scanning. Mellahi et al.'s (2002, p. 25) contention that "company vulnerability" is partly generated by an "improper response to external forces" is relevant here. Indeed, former directors admit that even they had little faith in the decisions they were taking with regard to new store openings:

We opened in odd places like Stevenage, but ultimately Oxford Street [the UK's premier retail location in London], and I remember we just weren't ready to trade there. I think it was a massive loss maker, but by that time everything was coming apart... The English weren't going to just throw their arms around Wrygges. (Director C)

In summary, the key to AGS's downfall appears to come in a path of decisions that led to the sale of the Style Card in 1985, and which subsequently affected the investment of the proceeds. The decision to spend the money from Style on Wrygges' rapid and ultimately damaging expansion into England emphasizes the way in which a single critical event can affect long-term outcomes. All the above decisions lay with the board collectively, and whilst certain individuals and influences, both internal and external, may have pressurized the board to take such decisions, the company's strategic direction was ultimately their responsibility.

\subsection{Culpability}

The decisions leading to the sale of the Style Card and the spending of the proceeds lay with the board of AGS. Yet turning to the third objective of culpability, an important issue to note is that poor board experience, composition, and dynamics allowed this situation to arise in the first place. The lack of retail experience on the board has already been highlighted as problematic, and this problem went right to the top of the organization:

Mark [Goldberg] was very much a strategic chairman, very high level, high caliber individual, but he wasn't a retailer as such. He was not looking through figures on a Monday morning. (Director C)

Additionally, the fact the board was small and lacked churn undoubtedly exacerbated the absence of retail insight. Specifically, Mark Goldberg and Michael Marks were on the board from 1974 until the company's demise. Three other directors with finance, facilities and legal roles completed the full-time directors. The internal appointees replacing these three individuals on their retirement had spent their directorial (or indeed entire) careers with AGS. In 1988, AGS appointed the company's first non-executive director, but he too came from a non-retail background.

The issue of culpability starts to take on an additional dimension in light of the fact that the board received advice to change their composition and structure as early as 1981 . This was the year two directors first attended the Harvard Managing Organizational Effectiveness Program (Spector and Beer, 1983), which involved them reflecting on the company strategy and structure; an exercise repeated in 1983 (Beer and Kaftan, 1985). What emerges clearly from the Harvard cases are the tensions of working for a firm with strong family ties, the reliance of the business on the Style Card, but most of all the lack of directors with relevant outside experience. This emphasizes the problems the company faced in grasping new ways of thinking, as leaders had been born within, and indoctrinated into the existent company culture. In 1989, AGS called in consultants Paul Jago and Associates (Jago, 1989) to help find a new chief executive. Jago's report on the board's composition and experience suggests little had changed in the boardroom skill set, with the following damning observation: "I am struck that no board member has ever worked for a retailer. This is a glaring gap".

Taking into account the above, the matter of culpability becomes a multi-layered affair. Early advice from the Harvard reports was to recruit a director with external retail experience at board level (Spector and Beer, 1983). If the issue of board composition had been handled better, then the board in 1985 may have had more retail experience. More judicious spending of the proceeds from the sale of the Style Card may have avoided subsequent problems. Equally important was the marketing of the Style Card to non-competing retailers, leading to the credit business growing and the core retail business diminishing-a decision that might not have happened with 
a better-constituted board. Yet referring to one new boardroom appointee, Director D opined that he was "not too sure that the boardroom made [him] too welcome", suggesting that resistance to any form of change was always going to be high.

The consultancy reports criticizing the directorial balance were not the only advice taken lightly. An external review from 1988 criticizes fascias such as Wrygges as "having weak recognition in England" (Burke Market Research, 1988). Again, no one thought to act on this information in a meaningful way. Indeed, the 1989 annual report admits that the plan for the previous year "was to increase profits in Wrygges... through aggressive expansion in England" (A Goldberg and Sons, 1989). The fact that AGS called on such expert support and insight is certainly not an act of culpability in this case of organizational failure. However, the issue of responsibility does become apparent given that the directorate rarely acknowledged, or acted on, resultant advice.

\section{Discussion}

This paper seeks to determine and deconstruct notions of blame surrounding failure at AGS, via three research questions, the first being: did the company's directorate have knowledge of impending failure? This question of whether the AGS directorate could, or at least should, have known that things were going wrong relates to the notion of foreseeability from Shaver's model. Evidence suggests the directors were fully aware of the critical state of the company long before calling in the receivers, not least because of their banker's prior concerns.

Also, various financial KPIs show the parlous state of the operation some years before the eventual collapse. The research indicates that the directorate members were cognizant of the disappointing side to the company's financial performance and the problems this was highlighting. In addition, although the poorer financials were, at worst, ignored in the spin of company reports or, at best, merely put down to pressures from the macro-environment, findings suggest that behind the scenes the directorate were not so optimistic. They clearly should and could have had knowledge of impending company failure, or at least the increasing potential for failure to occur.

The second research question, based around the notion of causality in blame attribution, asks to what extent the board's decision-making led to failure. Interview evidence demonstrates that the failure of AGS has roots in a series of linked decisions based around the sale of the Style Card in 1985, and the usage of those sale proceeds. Ultimately, these decisions lay with the board and as such the board's actions were the cause of failure. Personality clashes and problematic interactions around the boardroom table may also have adversely affected the outcomes of the board as a decision-making unit. As one interviewee explains:

I don't think we directors were confident enough of ourselves to confront Mark around the boardroom table. I would run and see Mark when I wasn't happy about something and he would either soft talk me round or he would say, "I'll think about that" ... He was too nice a guy, I was too nice a guy... but looking beyond that you need an asshole. (Director D)

The final research question concerns the question of culpability for failure and specifically the issue of responsibility or blameworthiness. The sequence of poor decision-making indicates, initially, that the board was culpable. The reality appears to be more complex and subtle. The board's composition in the years immediately before the company's failure was a result of earlier inabilities to react to criticism regarding the balance of boardroom personnel, skills and expertise. The suggestion is that culpability for AGS's demise is cumulative and multi-layered; a linked number of events building up over time, a series of sequential bad decisions with no underlying intent to cause failure.

The fact that some level of foreseeability for AGS's failure exists amongst the directorate, countered by clear multiple causes and lack of intent, suggests that in organizational terms the directors can be attributed with what Shaver terms "lesser negligence" for the company's demise. In terms of his blame attribution model, lesser negligence is a far lesser charge than being responsible or blameworthy, which in this instance would typically require a single definable cause of failure and at least some level of intent (Shaver, 1985, p. 166).

\section{Conclusion}

This study makes two contributions. The first is a methodological point and concerns the way in which archival research combines and cross-references with present-day interviews to help in the deconstruction and subsequent understanding and attribution of blame in business failure. As well as having academic value, the ability to be able to deconstruct blame in corporate failure, most notably in terms of the dimensions of foreseeability, causality, and culpability, should further practitioner understanding of why that failure has occurred and provide lessons for the future.

The other key contribution is theoretical. The above suggests that more work incorporating blame theories from social psychology with the existing body of work on corporate failure is required. This paper represents a first attempt at achieving that task. The study demonstrates how, with sufficient evidence and investigation, blame in cases of corporate failure can be conceptualized in terms of key dimensions and then mapped onto an existing model of blame attribution theory from social psychology. In academic terms, such a model provides a possible template for further comparative investigations of blame attribution outcomes in failing companies. In particular, is Shaver's (1985) notion of "lesser negligence", attributable to AGS's directorate in relation to the company's demise, a typical or atypical blame outcome in cases of corporate failure?

In summary, this paper places accountability for AGS's failure with the directorate. Their critical decisions surrounding the sale of Style in part brought this failure about; but so too did the subsequent application of these funds to rapid retail expansion at the height of the property market. The directorate also had an underlying duty for the composition of the board, and as such was liable for its apparent active inertia in decision-making.

The failure of AGS was not the result of bad people. Indeed, the judge at the 1997 court case notes that the ex-directors were "men of unquestioned integrity ... held in the highest esteem" with no questions arising "as to their credibility or reliability" (Scottish Civil Law Reports, 1997, p. 4). Minimal evidence of blame shifting or excuses exists amongst the directorate for the failure, as can sometimes be the case in other organizations (Bovens, 1998; Tsang, 2002). This acceptance corroborates with the admission of one former director that:

... along with other colleagues, I shoulder my share of the blame. I made some poor recommendations and did not always stand my ground when I should have. It was not deliberate, just a reflection of my own relative inexperience at the time. (Director E)

The antecedents of AGS's failure are most evident in a collective lack of experience at board level. As serious problems became apparent, few of the directors seem to recognize the indicators and warning signs. Twenty years on, the continued success of Ted Baker and Schuh, both of which former AGS directors bought, indicates that in different circumstances the latent directorial skills were there to maintain a viable business. Such successes also suggest former directors may have learnt from the experience of being part of a corporate failure. 


\section{References}

A Goldberg and Sons. Annual report; 1983. UGD354.

A Goldberg and Sons. Annual report; 1986a. UGD354.

A Goldberg and Sons. Board meeting papers. 10 October; 1986b. UGD 354.

A Goldberg and Sons. Annual report; 1989. UGD354.

Altman E. Financial ratios, discriminant analysis and the prediction of corporate bankruptcy. J Finance 1968;23:589-609.

Altman E, Narayanan P. An international survey of business failure classification models. Financ Mark Inst Instrum 1997;6:1-57.

Altman E, Haldeman R, Narayanan P. Zeta analysis: a new model to identify bankruptcy risk of corporations. J Bank Finance 1977;1:29-54.

Andersen Arthur. Small store survival: success strategies for retailers. Chichester: John Wiley; 1997.

Arnold S. Lessons learned from the world's best retailers. Int J Retail Distrib Manage 2002;30:562-70.

Balcaen S, Ooghe H. 35 years of studies on business failure: an overview of the classic statistical methodologies and their related problems. Br Acc Rev 2006;38:63-93.

Beaver W. Financial ratios as predictors of failure. J Acc Res 1966;4:71-111.

Beer M, Kaftan C. A Goldberg \& Sons plc (B). (Harvard Business School, Case 9-485-024) Boston, MA: Harvard Business School; 1985.

Berry L, Seiders K, Gresham L. For love and money: the common traits of successful retailers. Organisational Dyn 1997;26:7-23.

Bevan J. The rise and fall of Marks and Spencer. London: Profile Books; 2001.

Bhargava M, Dubelaar C, Scott T. Predicting bankruptcy in the retail sector: an examination of key measures of performance. J Retailing Consum Serv 1998;5:105-17.

Bird JH, Witherwick ME. Marks and Spencer: the geography of an image. Geography 1986;71:305-19.

Bovens M. The quest for responsibility. Cambridge: Cambridge University Press; 1998

Bowditch G. Goldberg fails after 50 years. The Times 1990; 8 June.

Bubb N. Goldberg company research. Citicorp Scrimgeour Vickers, Investext 305428, 4 November, 1983.

Bubb N. Goldberg company report. Citicorp Scrimgeour Vickers, Investext 412195, 19 November, 1984.

Burke Market Research. Market Research Report: 1988. UGD354.

Burt SL, Mellahi K, Jackson T, Sparks L. Retail internationalization and retail failure: issues from the case of Marks and Spencer. Int Rev Retail Distrib Consum Res 2002;12:191-219.

Burt S, Dawson J, Sparks L. Failure in international retailing: research propositions. Int Rev Retail Distrib Consum Res 2003;13:355-73.

Chapman S. Jesse Boot of Boots the Chemists: a study in business history. London: Hodder and Stoughton; 1974.

Davies G, with Davies J. What Next? London: Arrow Books, 1991.

Deakin E. A discriminant analysis of predictors of business failure. J Acc Res 1972;10: $167-79$.

Dorgan P. Goldberg company report. Citicorp Scrimgeour Vickers, Investext 404908, 1984

Gardner H. Rise, fall and regeneration: Woolworth: the UK experience since 1909 Manage Case Q 1995;1:13-28.

Gibson D, Schroeder S. Who ought to be blamed? The effect of organizational roles on blame and credit attributions. Int J Confl Manage 2003;14:95-117.

Gold P, Woodliffe LH. Department stores in Spain: why El Corte Inglés succeeded where Galerías Preciados failed. Int J Retail Distrib Manage 2000;28:333-40.

Golder PN. Historical methods in marketing research with new evidence on long-term market share stability. J Mark Res 2000;37:156-72.

Hamilton V. Who is responsible? Toward a social psychology of responsibility attribution. Soc Psychol 1978:41:316-28.

Hamilton V, Blumenfeld P, Kushler R. A question of standards: attributions of blame and credit for classroom acts. J Pers Soc Psychol 1998;54:34-48.

Harris L. Merchant princes: an intimate history of Jewish families who built great department stores. New York: Harper \& Row; 1979.

Howe S. William Low \& Co: a family business history. Dundee: Abertay Historical Society; 2000
Jago P. Briefing document on search for new Chief executive; 1989. UGD 354.

Jones D. Next to me: luck, leadership and living with Parkinson's. London: Nicholas Brealey; 2005.

La Vere S, Kleiner B. Practice of excellent companies in the retail industry. Managing Serv Qual 1997:7:34-8.

Lightfoot W. Multi-channel mistake: the demise of a successful retailer. Int J Retail Distrib Manage 2003;31:220-9.

MacLaurin I. Tiger by the tail: a life in business from Tesco to test cricket. London: Macmillan; 1999.

Maltz A, Shenar A, Reilly R. Beyond the balanced scorecard: refining the search for organizational success measures. Long Range Plann 2003;36:187-204.

McGurr P, DeVaney S. Predicting business failure of retail firms: an analysis using mixed industry models. J Bus Res 1998a;43:169-76

McGurr P, DeVaney S. A retail failure prediction model. Int Rev Retail Distrib Consum Res 1998b;8:259-76.

Mellahi K, Wilkinson A. Organizational failure: a critique of recent research and a proposed integrative framework. Int J Manage Rev 2004;5(6):21-41.

Mellahi K, Jackson P, Sparks L. An exploratory study into failure in successful organisations: the case of Marks \& Spencer. Br J Manage 2002;13:15-29.

Michman R, Greco A. Retailing triumphs and blunders: victims of competition in the new age of marketing. London: Quorum Books; 1995.

Miller D, Merrilees B. "Gone to Gowings"-an analysis of success factors in retail longevity: Gowings of Sydney. Serv Ind J 2000;20:61-85

Morris R. Early warning indicators of corporate failure: a critical review of previous research and further empirical evidence. Aldershot: Ashgate; 1997.

O'Donoghue J, McDonnell C, Placek M. Consumer price inflation: 1947-2004. Economic Trends 2006;626:38-54.

Powell D. Counter revolution: the Tesco story. London: Grafton; 1991.

Rauh T. Accounting: early warning systems for troubled retailers. Commercial Lending Rev 1989/1990; 5: 59-69.

Richer J. The richer way. London: Emap; 1998.

Scottish Civil Law Reports. Style Financial Services Ltd versus Governor and Company of the Bank of Scotland. Court of Session: Outer House, 21 January, 1997.

Seth A, Randall G. The grocers: the rise and rise of the supermarket chains. London: Kogan Page; 1999.

Sharma S, Mahajan V. Early warning indicators of business failure. J Mark 1980;44: 80-9.

Shaver K. The attribution of blame: causality, responsibility and blameworthiness. New York: Springer; 1985

Sieff M. Don't ask the price: the memoirs of the president of Marks \& Spencer. London: Weidenfeld and Nicolson; 1986.

Sieff M. Management: the Marks \& Spencer way. London: Fontana/Collins; 1991.

Sparks L. A catalogue of success? Argos and catalogue showroom retailing. Serv Ind J 2003;23:79-111.

Spector B, Beer M. A Goldberg \& Sons plc (A). (Harvard Business School, Case 9-483-110) Boston, MA: Harvard Business School; 1983.

Sull DN. Why good companies go bad and how great managers remake them. Boston, MA: Harvard Business School Press; 2005a.

Sull DN. Ingrained success breeds failure. Financial Times 2005, 3 October, p. 12.

Taffler RJ. Empirical models for the monitoring of UK corporations. J Bank Finance 1984;8:199-227.

Thompson A-MK. Golder's historical method in research in marketing. J Bus Res 2010;83:1269-72.

Tsang E. Self-serving attribution in corporate annual reports: a replicated study. J Manage Stud 2002;39:51-65.

Turner M. K-Mart's 10 deadly sins: how incompetence tainted an American icon. Hoboken, NJ: John Wiley; 2003.

UGD 354 A Goldberg \& Sons plc archive. Glasgow University, Scotland (n.d.).

Wagner J, Gooding R. Equivocal information and attribution: an investigation of patterns of managerial sensemaking. Strateg Manage J 1997:18:275-86.

Walker E. 100 years of shopping at Boots, 1877-1977. Nottingham: Boots Co. Ltd; 1978. 